\title{
Analisis Pigmen Alami Daun Mangga (Mangifera Indicalinn) Sebagai Pewarna Batik Dengan UV-VIS
}

\author{
${ }^{1}$ Ni Komang Tribuana Cipta Putri, ${ }^{2}$ I Gst Agung Ayu Ratnawati, ${ }^{3}$ Wayan Gede Suharta \\ ${ }^{1}$ Program Studi Fisika, Fakultas Matematika dan Ilmu Pengetahuan Alam, Universitas \\ Udayana,Kampus Bukit Jimbaran, Badung, Bali, Indonesia 80361 \\ Email:tribuanacipta5@gmail.com; iga.ratnawati@yahoo.com;wgsuharta@gmail.com
}

\begin{tabular}{|c|c|}
\hline Article Info & Abstract \\
\hline $\begin{array}{l}\text { Article History } \\
\text { Received: October } \\
\text { Revised: Nopember } \\
\text { Published: December } \\
\text { Keywords } \\
\text { Mangifera Indica Linn, } \\
\text { UV-VIS, Chlorophyll }\end{array}$ & $\begin{array}{l}\text { The development of the batik industry has caused batik consumption to } \\
\text { increase. Increased clothing and lifestyle needs trigger the need for practical } \\
\text { (synthetic) dyes to have an impact on the waste produced. To reduce negative } \\
\text { effects, the use of natural dyes needs to be increased. One of the plants that } \\
\text { produce natural dyes is mango (Mangifera Indica Linn). Mango plants } \\
\text { (Mangifera Indica Linn) including the family Anacardiaceae. The leaves } \\
\text { contain a lot of chlorophyll which can produce color pigments for textiles. To } \\
\text { find out the potential, an UV-VIS analysis was carried out, namely absorbance } \\
\text { and calculation of the amount of chlorophyll contained in the leaves. The } \\
\text { method used is the maceration process with technical ethanol solvents, with } \\
\text { variations in concentration (70\% and } 96 \% \text { ) and variations in the immersion } \\
\text { time (3 hours, } 5 \text { hours, } 10 \text { hours, } 20 \text { hours). From the results of UV-VIS } \\
\text { spectrophotometry analysis showed the maximum absorption or absorbance at } \\
\text { a concentration of } 96 \% \text { for } 5 \text { hours and the calculation of chlorophyll by the } \\
\text { Lichtenthaler \& Welburn (1983) method showed that the sweet arum manggu } \\
\text { leaves used for research contained more chlorophyll b than chlorophyll a, } \\
\text { gives a greenish-yellow pigment with wavelengths of } 540 \text { nm and } 640 n m \text {. }\end{array}$ \\
\hline InformasiArtikel & Abstrak \\
\hline $\begin{array}{l}\text { SejarahArtikel } \\
\text { Diterima: Oktober } \\
\text { Direvisi: November } \\
\text { Dipublikasi:Desember } \\
\text { Kata kunci } \\
\text { Mangifera Indica Linn, } \\
\text { UV-VIS, Klorofil }\end{array}$ & $\begin{array}{l}\text { Perkembangan industri batik menyebabkan konsumsi batik semakin meningkat. } \\
\text { Peningkatan kebutuhan sandang serta gaya hidup memicu kebutuhan zat warna } \\
\text { yang praktis (sintetis) berdampak pada limbah yang dihasilkan. Untuk } \\
\text { mengurangi dampak negatif, penggunaan zat warna alami perlu ditingkatkan. } \\
\text { Salah satu tanaman yang menghasilkan zat warna alami yaitu tanaman mangga } \\
\text { (Mangifera Indica Linn). Tanaman mangga (Mangifera Indica Linn)termasuk } \\
\text { famili Anacardiaceae. Pada bagian daunnya banyak mengandung klorofil yang } \\
\text { dapat menghasilkan pigmen warna untuk tekstil. Untuk mengetahui potensi di } \\
\text { lakukan analisis dengan alat UV-VIS yaitu absorbansi dan perhitungan jumlah } \\
\text { klorofil yang terkandung pada daun. Metode yang digunakan adalah proses } \\
\text { maserasi dengan pelarut etanol teknis, dengan variasi konsentrasi (70\% dan } \\
\text { 96\%) dan variasi waktu perendaman (3jam, 5jam, } 10 \text { jam, } 20 \text { jam). Dari hasil } \\
\text { analisis spektrofotometri UV-VIS memperlihatkan hasil serapan atau } \\
\text { absorbansi maksimum pada konsentrasi } 96 \% \text { selama } 5 \text { jam dan perhitungan } \\
\text { klorofil dengan metode Lichtenthaler \& Welburn (1983) memperlihatkan } \\
\text { bahwa daun manggu arum manis yang dipakai untuk penelitian lebih banyak } \\
\text { mengandung klorofil b dibandingkan klorofil a, memberikan pigmen hijau- } \\
\text { kekuningan dengan panjang gelombang } 540 \text { nm dan 640nm. }\end{array}$ \\
\hline \multicolumn{2}{|c|}{$\begin{array}{l}\text { Sitasi: Putri, N.K.T.C., Ratnawati, I.G.A.A., Suharta, W.G. (2019). Analisis Pigmen Alami Daun Mangga } \\
\text { (Mangifera Indicalinn) Sebagai Pewarna Batik Dengan UV-VIS. Kappa Journal, Pendidikan Fisika, FMIPA, } \\
\text { Universitas Hamzanwadi. 3(2), 134-141 }\end{array}$} \\
\hline
\end{tabular}

\section{PENDAHULUAN}

Dewasa ini, penggunaan pewarna alami semakin meningkat sejalan dengan perkembangan industri batik yang semakin maju. 
Penggunaan zat warna alami seyogyanya tidak diperhgunakan secara besar-besaran, mengingat zat tersebut berasal dari tumbuh-tumbuhan. Sedangkan tumbuhan penghasil zat pewarna memerlukan waktu untuk tumbuh. Untuk mengatasi hal tersebut, maka dilakukan penelitian-penelitian yang berkaitan dengan efektivitas dan optimalisasi penggunaan zat warna alami tersebut, baik dari metode pemrosesan maupun mencari alternatif tanaman lain yang potensial dimanfaatkan sebagai pewarna batik (Vivin, dkk., 2016).

Peningkatan kebutuhan sandang serta gaya hidup juga berpengaruh terhadap perkembangan industri tekstil yang sangat pesat seperti industri batik. Pertumbuhan tersebut memicu kebutuhan zat warna yang praktis (sintetis) berdampak pada limbah yang dihasilkan. Sampah cair bekas produksi tersebut menjadi limbah yang mengandung zat warna sintetis dengan berbagai kandungan logam berbahaya (Budi, 2016). Pertumbuhan industri batik di Indonesia tampaknya dipengaruhi oleh pengakuan dunia melalui UNESCO (United Nations Educational, Scientific, andCultural Organization), dimana UNESCO mengakui industri batik di Indonesia sebagai warisan budaya asli Indonesia pada tanggal 2 Oktober 2009 di Prancis. Namun dibalik prestasi perkembangan industri yang membanggakan tersebut, terselip sejumlah masalah terkait pencemaran limbah yang dihasilkan (Muniarti, dkk., 2015). Maka untuk mengurangi dampak negatif, penggunaan zat warna alami perlu ditingkatkan. Salah satu tanaman yang menghasilkan zat warna alami yaitu tanaman mangga dengan nama latin Mangifera Indica Linn.

Tanaman mangga (Mangifera Indica Linn) termasuk famili Anacardiaceae. Pada bagian daunnya banyak mengandung klorofil yang dapat menghasilkan pigmen warna untuk tekstil. Pigmen yang terkandung dalam daun mangga adalah pigmen mangiferine. Sedangkan pigmen mangiferine mengandung gugus kromofor seperti karbonil dan gugus auksokrom seperti hidroksil. Pigmen mangiferine merupakan jenis dari pada xanton (zat warna) yang dapat digunakan sebagai bahan pewarna alami sangat karena mudah melepaskan zat warna pada bahan kain. Daun mangga berpotensi dijadikan alternatif pewarna alami batik karena kandungan zat hijau atau klorofil yang ada pada daun mangga. (Rindy, dkk., 2010). Maka dilakukan penelitian untuk menganalisis sifat optik yaitu analisis absorbansi dari pigmen alami yang diperlukan untuk mengungkapkan jenis pigmen serta potensi aplikasi pigmen yang terkandung dalam daun mangga yang akan dijadikan sebagai pewarna batik.

\section{METODE}

Daun yang digunakan pada proses ektraksi adalah daun mangga arum manis, yang dikeringkan ( \pm 1 minggu). Daun yang kering diblender hingga menjadi serbuk halus.Untuk mendapatkan hasil analisis baik absorbansi dan analisis pada pigmen warna perlu dilakukan proses ekstraksi. Proses ekstraksi bertujuan untuk mengambil senyawa kimia yang terkandung dalam daun. Tujuan proses ekstraksi adalah agar terjadi perpindakan massa pada lapisan antar muka dan berdifusi masuk ke dalam pelarut, berdasarkan perpindahan masa komponen zat yang terlarut ke dalam pelarut. Metode ekstraksi yang digunakan pada penelitian ini adalah maserasi, karena metode ini lebih sederhana, mudah dan tanpa pemanasan. Pelarut yang digunakan pada penelitian ini adalah etanol teknis sebagai pelarut polar, karena etanol memiliki kelebihan dibandingkan dengan air dan metanol. Senyawa kimia yang mampu diekstrak dengan etanol lebih banyak dari pada pengekstrak metanol dan air. Pelarut etanol teknis yang digunakan adalah konsentrasi $70 \%$ dan $96 \%$ dengan perbandingan 1:5 atau $50 \mathrm{gr}: 250 \mathrm{ml}$. Waktu perendaman divariasikan sebesar 3, 5, 10 dan 20 jam. Untuk mengkaji lebih lanjut proses analisis dilakukan dengan metode analisis spektrofotometri UV-VIS untuk mencari nilai absorbansi.Untuk mengkaji pigmen yang terkandung dalam daun seperti klorofil perlunya dilakukan pengukuran klorofil untuk menghitung klorofil a, klorofil b. Pengukuran klorofil dirumuskan dengan metode Lichtenhaler \& Welburn (1983), nilai yang dibaca adalah nilai absorbansi filtrat pada panjang gelombang 649 dan $665 \mathrm{~nm}$. 


\section{HASIL DAN PEMBAHASAN}

1. Hasil Karakterisasi Grafik Absorbansi dengan Etanol Teknis 70 dan $96 \%$

Hasil karakterisasi UV-VIS untuk sampel daun mangga yang telah diekstrak menggunakan pelarut etanol teknis 70 dan 96\% dengan waktu maserasi selama 3, 5, 10, dan 20 jam diperlihatkan pada Gambar $1, \quad 2, \quad 3 \quad$ dan 4.

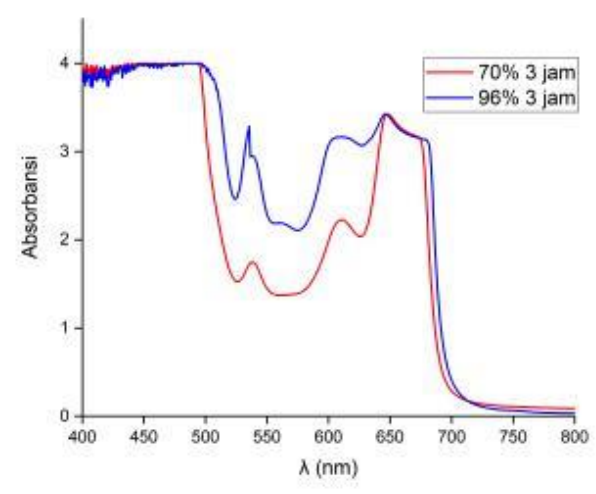

Gambar 1. Grafik absorbansi 3 jam

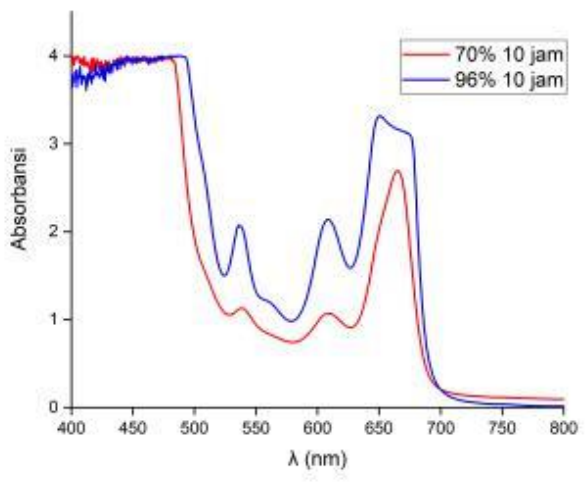

Gambar 3. Grafik absorbansi10 jam

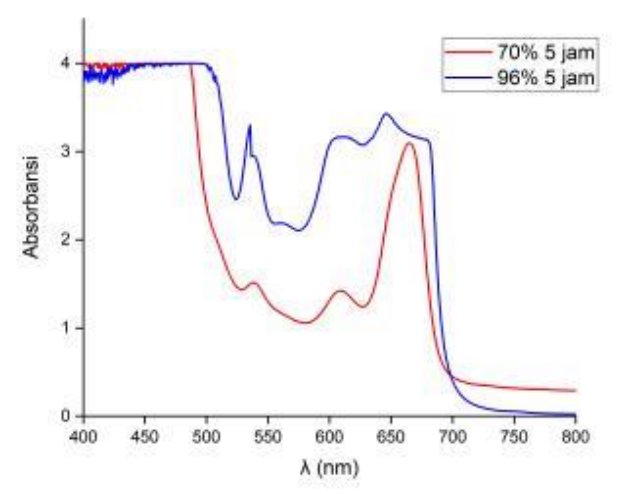

Gambar 2. Grafik absorbansi 5 jam

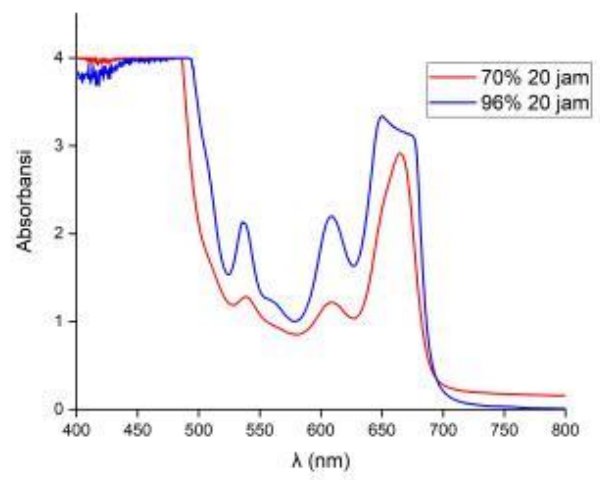

Gambar 4. Grafik absorbansi 20 jam

Tabel 1. Data Absorbansi yang sudah dikurangi dengan background.

\begin{tabular}{|c|c|c|c|c|c|c|c|c|}
\hline \multirow{2}{*}{ konsentrasi } & \multicolumn{2}{|c|}{$\mathbf{3}$ jam } & \multicolumn{2}{c|}{$\mathbf{5}$ jam } & \multicolumn{2}{c|}{$\mathbf{1 0}$ jam } & \multicolumn{2}{c|}{ 20 jam } \\
\cline { 2 - 9 } & $\boldsymbol{\lambda} \mathbf{( n m )}$ & Absorbansi & $\boldsymbol{\lambda}(\mathbf{n m})$ & Absorbansi & $\boldsymbol{\lambda} \mathbf{( n m})$ & Absorbansi & $\boldsymbol{\lambda}$ (nm) & Absorbansi \\
\hline & 648.5 & 3.219 & 665.5 & 2.706 & 665.5 & 2.519 & 664.5 & 2.695 \\
\hline $70 \%$ & 611 & 2.017 & 611 & 1.03 & 609 & 0.896 & 608.5 & 1.001 \\
\hline & 538.5 & 1.54 & 538.5 & 1.123 & 538.5 & 0.955 & 538.5 & 1.065 \\
\hline & 665.5 & 2.118 & 664 & 2.104 & 663.5 & 2.005 & 664 & 1.811 \\
\hline $80 \%$ & 608 & 0.778 & 606.5 & 0.791 & 606 & 0.815 & 606 & 0.734 \\
\hline & 538 & 1.006 & 536 & 1.494 & 535.5 & 1.102 & 535.5 & 1.033 \\
\hline & 646 & 3.137 & 646 & 3.24 & 650.5 & 3.187 & 649.5 & 3.192 \\
\hline & 610.5 & 2.879 & 609.5 & 2.98 & 608.5 & 2.008 & 609 & 2.055 \\
\hline & 560 & 1.902 & 561 & 2 & 535.5 & 1.941 & 535.5 & 1.988 \\
\hline
\end{tabular}

Absorbansi merupakanperbandingan dari intensitas sinar yang diserap dengan intensitassinar yang datang. Nilai absorbansi ini bergantung pada kadarzat yang terkandung didalam suatu sampel, semakin banyak kadar zatyang terkandung dalam suatu sampel maka semakin banyakmolekul yang akan menyerap cahaya pada panjang gelombangtertentu, sehingga nilai 
pada absorbansi semakin besar atau dapat dikatakan bahwa nilai absorbansi akan berbanding lurus dengankonsentrasi zat yang terkandung didalam suatu sampel (Neldawati,dkk., 2013). Dari hasil spektrofotometri analisis data pada grafik memperlihatkan bahwa hasil analisis pada waktu 3 jam memperlihatkan titik puncak absorbansi (A) maksimum sebesar 3.129 dengan panjang gelombang $(\lambda)$ sebesar $648.50 \mathrm{~nm}$, pada waktu 5 jamtitik puncak absorbansi maksimum sebesar 3.240 dengan panjang gelombang $646.00 \mathrm{~nm}$, pada waktu 10 jam titik puncak absorbansi maksimum sebesar 3.187 dengan panjang gelombang $650.50 \mathrm{~nm}$, pada waktu 20 jam titik puncak absorbansi maksimum sebesar 3.129 dengan panjang gelombang $649.50 \mathrm{~nm}$. Seluruh Puncak absorbansi maksimum terletak pada konsentrasi $96 \%$ karena pelarut etanol teknis $96 \%$ hampir mencapai kemurnian dan kadar air yang terkandung dalam etanol

\section{Hasil Perhitungan Klorofil}

Hasil perhitungan klorofil a dan b dengan menggunakan pelarut etanol teknis70 dan 96\%, dengan waktu 3, 5, 10, 20 jam dengan rumus Lichtenthaler \& Welburn (1983)nilai yang dibaca adalah nilai absorbansi filtrat pada panjang gelombang 649 dan $665 \mathrm{~nm}$ di perlihatkan pada Tabel 1, 2, 3 dan 4 .

Tabel 1. Klorofil a dan b (3 jam)

\begin{tabular}{ccccc}
\hline \multicolumn{5}{c}{ Klorofil a } \\
\hline $\begin{array}{c}\text { Konsentrasi } \\
\text { (\%) }\end{array}$ & $\begin{array}{c}\text { Waktu } \\
\text { (jam) }\end{array}$ & $\boldsymbol{A}_{\mathbf{6 6 5}}$ & $\boldsymbol{A}_{\mathbf{6 4 9}}$ & Total Klorofil a \\
\hline 70 & 3 & 3.008 & 3.187 & 20.03504 \\
\hline 96 & 3 & 3.106 & 3.308 & 20.56966 \\
\hline \multicolumn{5}{c}{ Klorofil B } \\
\hline $\begin{array}{c}\text { Konsentrasi } \\
\text { (\%) }\end{array}$ & $\begin{array}{c}\text { Waktu } \\
\text { (jam) }\end{array}$ & $\boldsymbol{A}_{\mathbf{6 4 9}}$ & $\boldsymbol{A}_{\mathbf{6 6 5}}$ & Total Klorofil b \\
\hline 70 & 3 & 3.187 & 3.008 & 56.66847 \\
\hline 96 & 3 & 3.308 & 3.106 & 58.9386 \\
\hline
\end{tabular}

Tabel 2. Klorofil a dan b (5 jam)

\begin{tabular}{ccccc}
\hline \multicolumn{5}{c}{ Klorofil a } \\
\hline $\begin{array}{c}\text { Konsentrasi } \\
\text { (\%) }\end{array}$ & $\begin{array}{c}\text { Waktu } \\
\text { (jam) }\end{array}$ & $\boldsymbol{A}_{\mathbf{6 6 5}}$ & $\boldsymbol{A}_{\mathbf{6 4 9}}$ & Total Klorofil a \\
\hline 70 & 5 & 2.705 & 1.948 & 24.33251 \\
\hline 96 & 5 & 3.102 & 3.313 & 20.47946 \\
\hline \multicolumn{5}{c}{ Klorofil B } \\
\hline $\begin{array}{c}\text { Konsentrasi } \\
\text { (\%) }\end{array}$ & $\begin{array}{c}\text { Waktu } \\
\text { (jam) }\end{array}$ & $\boldsymbol{A}_{649}$ & $\boldsymbol{A}_{\mathbf{6 6 5}}$ & Total Klorofil b \\
\hline 70 & 5 & 1.948 & 2.705 & 28.29552 \\
\hline 96 & 5 & 3.313 & 3.102 & 59.09133 \\
\hline
\end{tabular}


Tabel 3. Klorofil a dan b (10 jam)

\begin{tabular}{ccccc}
\hline \multicolumn{5}{c}{ Klorofil A } \\
\hline $\begin{array}{c}\text { Konsentrasi } \\
\text { (\%) }\end{array}$ & $\begin{array}{c}\text { Waktu } \\
\text { (jam) }\end{array}$ & $\boldsymbol{A}_{\mathbf{6 6 5}}$ & $\boldsymbol{A}_{\mathbf{6 4 9}}$ & Total Klorofil A \\
\hline 70 & 10 & 2.52 & 1.487 & 24.92344 \\
\hline 96 & 10 & 3.037 & 3.177 & 20.50839 \\
\hline \multicolumn{5}{c}{ Klorofil B } \\
\hline $\begin{array}{c}\text { Konsentrasi } \\
\text { (\%) }\end{array}$ & $\begin{array}{c}\text { Waktu } \\
\text { (jam) }\end{array}$ & $\boldsymbol{A}_{649}$ & $\boldsymbol{A}_{665}$ & Total Klorofil B \\
\hline 70 & 10 & 1.987 & 2.52 & 30.61263 \\
\hline 96 & 10 & 3.177 & 3.037 & 56.20929 \\
\hline
\end{tabular}

Tabel 4. Klorofil a dan b (20 jam)

\begin{tabular}{ccccc}
\hline \multicolumn{5}{c}{ Klorofil A } \\
\hline $\begin{array}{c}\text { Konsentrasi } \\
\text { (\%) }\end{array}$ & $\begin{array}{c}\text { Waktu } \\
\text { (jam) }\end{array}$ & A665 & A649 & Total Klorofil A \\
\hline 70 & 20 & 2.695 & 1.734 & 20.32092 \\
\hline 96 & 20 & 3.028 & 3.186 & 25.66533 \\
\hline \multicolumn{5}{c}{ Klorofil B } \\
\hline $\begin{array}{c}\text { Konsentrasi } \\
\text { (\%) }\end{array}$ & $\begin{array}{c}\text { Waktu } \\
\text { (jam) }\end{array}$ & A649 & A665 & Total Klorofil B \\
\hline 70 & 20 & 1.734 & 2.695 & 23.55324 \\
\hline 96 & 20 & 3.186 & 3.028 & 57.3576 \\
\hline
\end{tabular}

\section{Diagram Perbandingan Klorofil a dan b.}

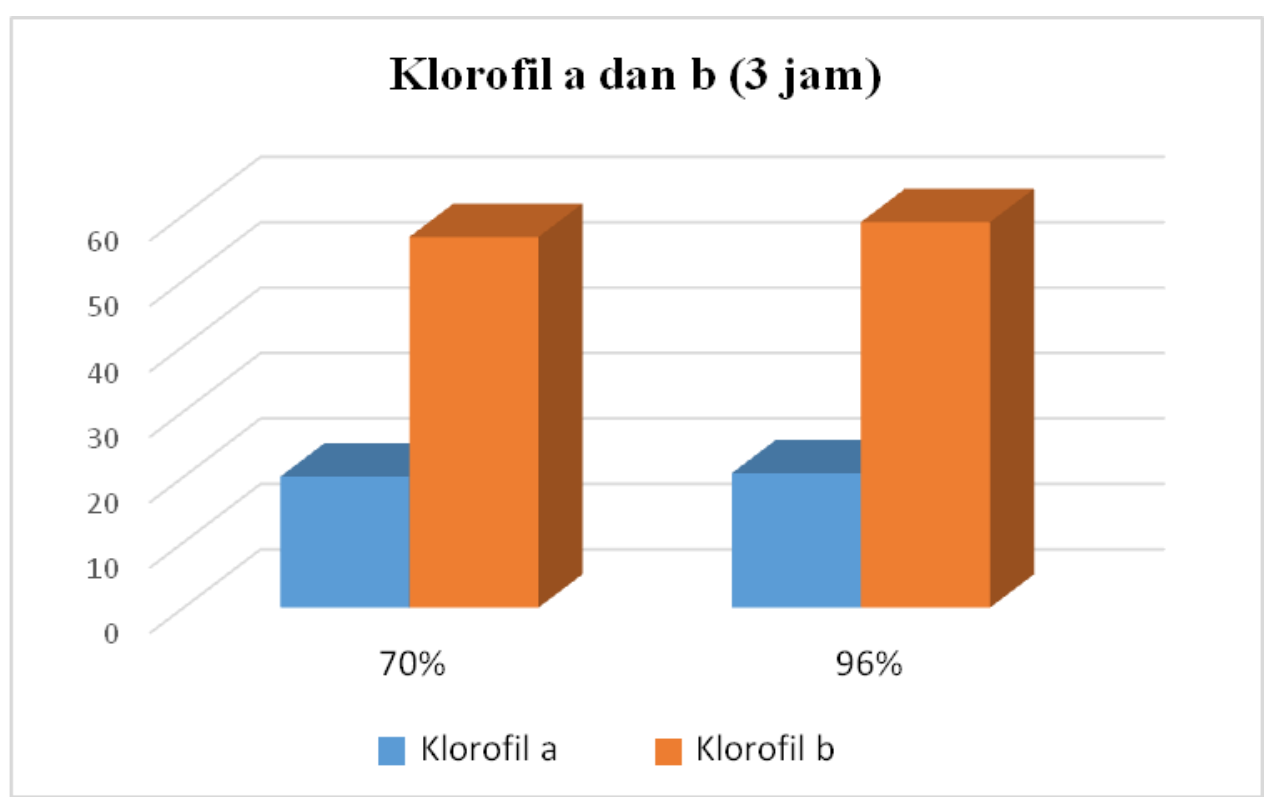

Gambar 5. Diagram klorofil a dan b (3 jam) 


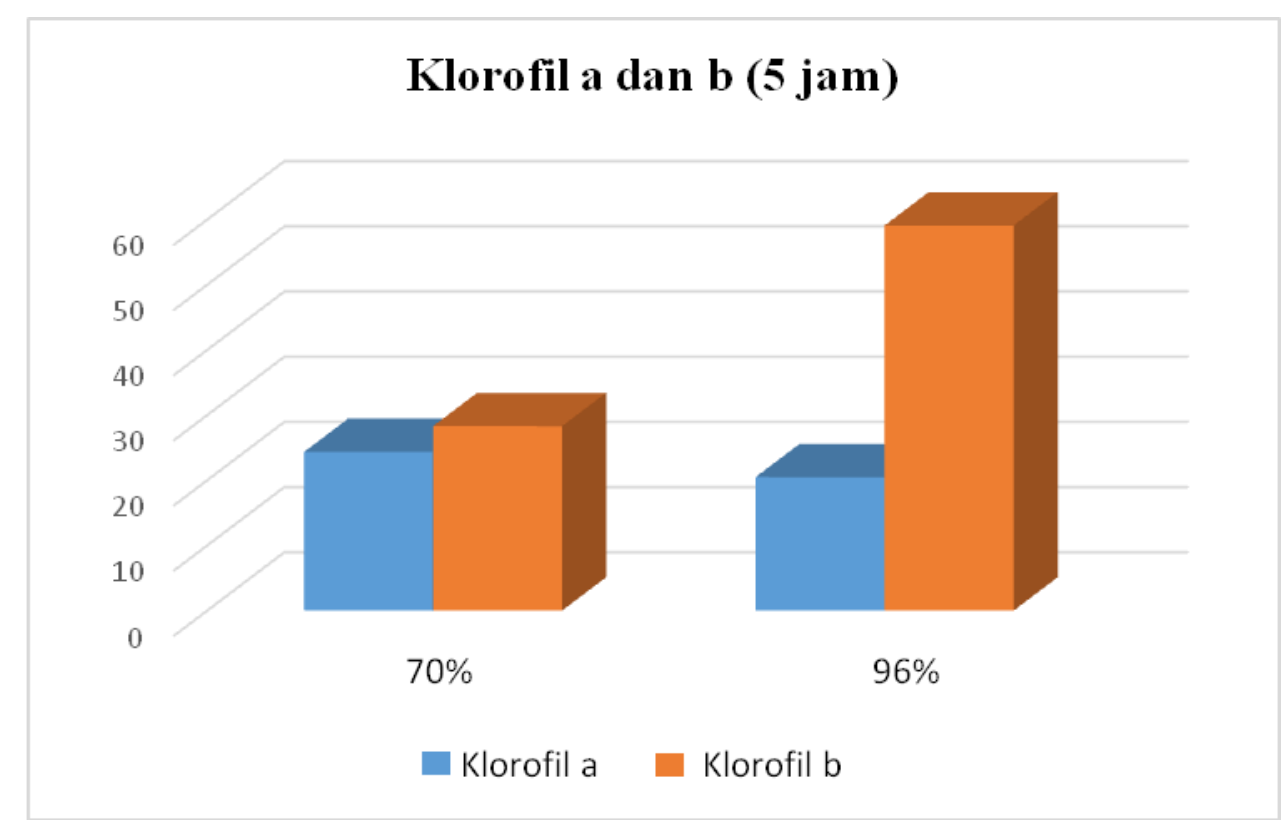

Gambar 6. Diagram klorofil a dan b (5 jam)

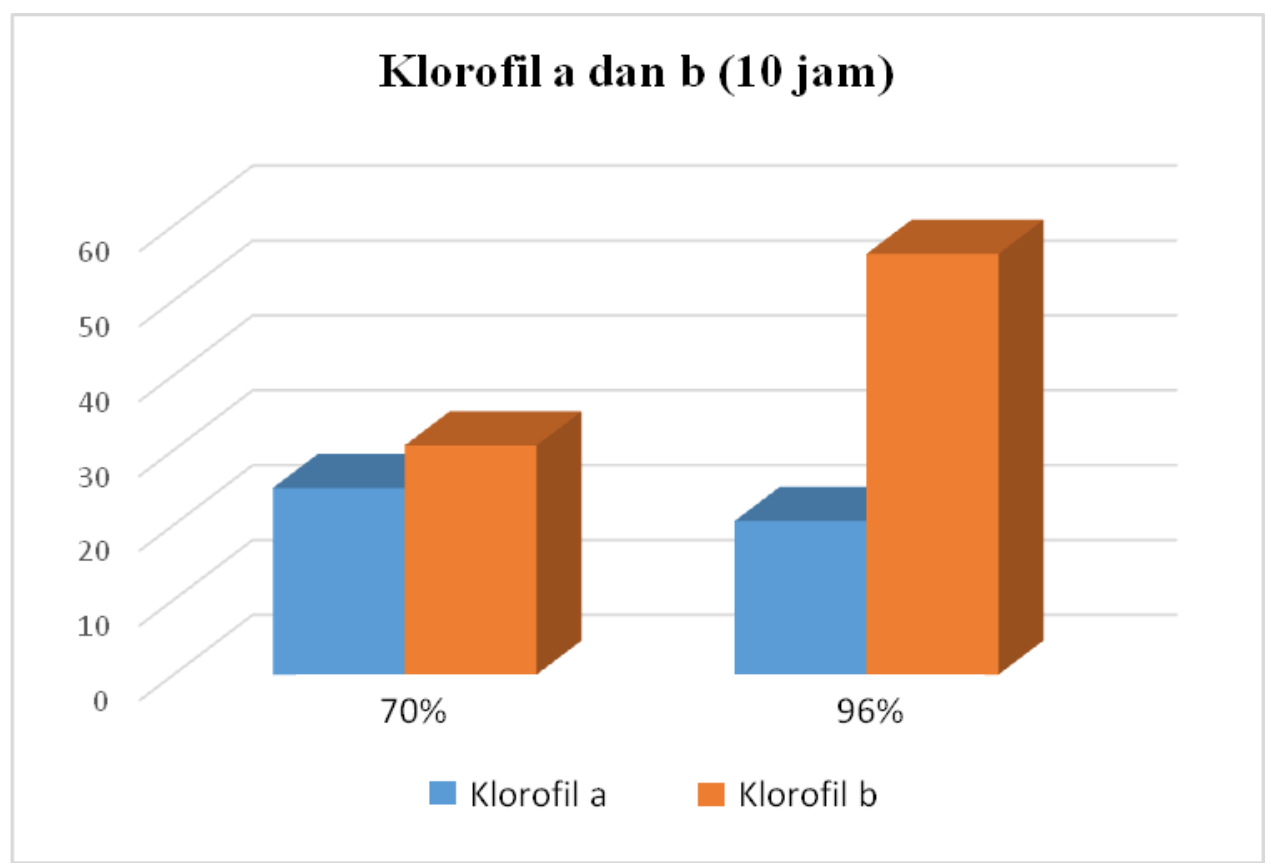

Gambar 7. Diagram klorofil a dan b (10 jam) 


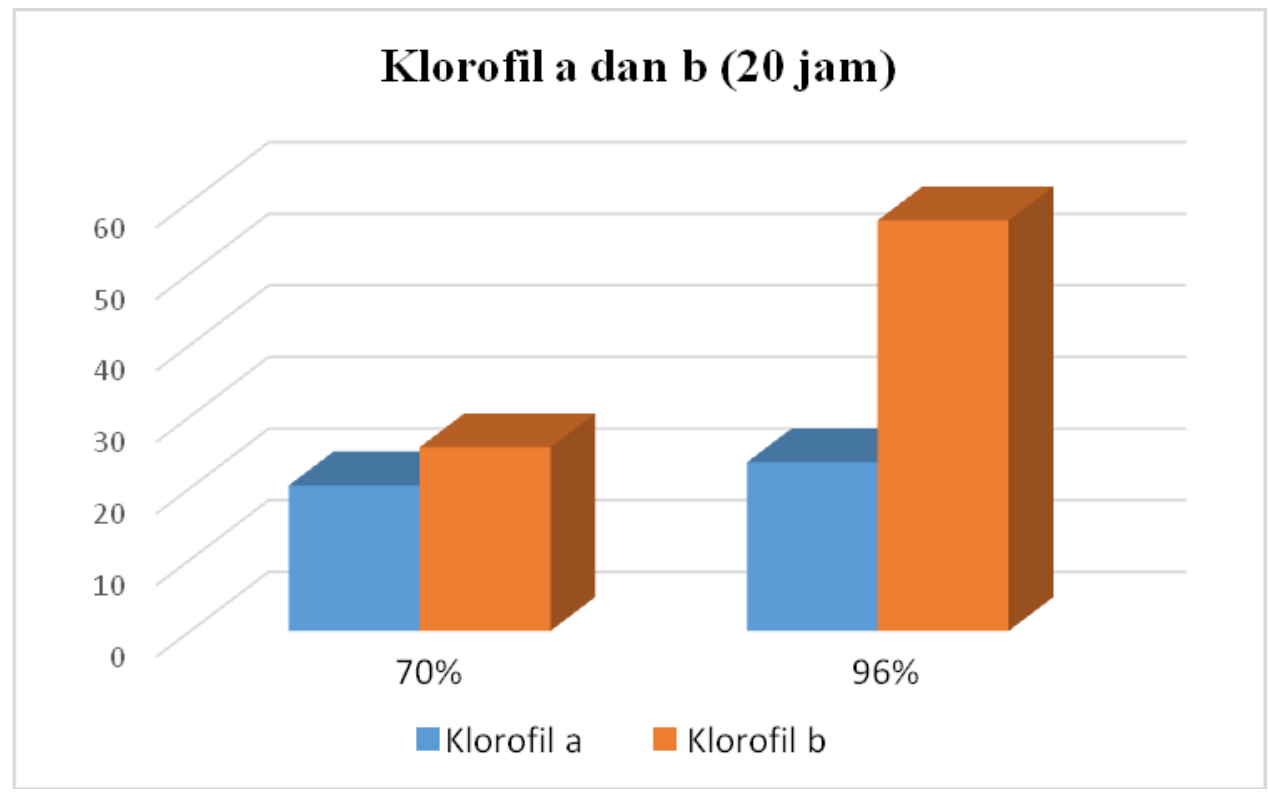

Gambar 8. Diagram klorofil a dan b (20 jam)

Daun mangga mengandung klorofil yang termasuk sebagai pigmen fotosintesis yang terdapat pada tumbuh-tumbuhan.Klorofil terdapat didalam kloroplas dan memanfaatkan cahaya yang diserap sebagai energy untuk reaksi cahaya. Secara spesifik, klorofil menyerap bagian cahaya merah dan biru-violet dari keseluruhan spektrum cahaya yaitu pada rentang 420 dan $660 \mathrm{~nm}$ dan merefleksikan cahaya hijau.Pemilihan pelarut termasuk salah satu faktor penting dalam pemrosesan ekstraksi. Klorofil lebih mudah terekstrak dengan pelarut etanol. Pengaruh dari hasil absorbansi bergantung pada material dari sampel. Klorofil a dan b memiliki nilai absorbansi pada panjang gelombang yang berbeda.Dari hasil perhitungan klorofil pada konsentrasi 70 dan 96\% pada waktu 3, 5, 10 dan 20 jam menunjukkan bahwa etanol teknis memiliki serapan pada klorofil b yaitu pada panjang gelombang $450-640 \mathrm{~nm}$. Klorofil b bertanggung jawab untuk mengumpulkan energi cahaya dan masuk ke klorofil aselama fotosintesis, klorofil b menyerap cahaya oranye-merah dari spektrum, warna yang dicerminkan adalah warna hijau-kekuningan. Kelarutan klorofil b tinggi dalam pelarut polar seperti etanol dan metanol dibandingkan dengan klorofil a.Pada klorofil $\mathrm{b}$ terdapat gugus aldehida (CHO), dengan berat molekulnya adalah 907.

\section{KESIMPULAN}

Berdasarkan hasil penelitian yang dilakukan maka dapat disimpulkan bahwahasil spektrofotometri pada pelarut etanol teknis dengan konsentrasi 70 dan 96\%dengan waktu perendaman selama 3, 5, 10, 20 jam memperlihatkan hasil serapan terbaik pada pelarut etanol teknis yaitu pada konsentrasi $96 \%$ yaitu pada waktu 5 jam, hal ini menandakan bahwa jika ingin menyerap zat warna dengan etanol teknis $96 \%$ hanya perlu dilakukan maksimum selama 5 jam. Daun mangga arum manis yang dipakai untuk penelitian terlihat lebih banyak mengandung klorofil $\mathrm{b}$ dibandingkan $\mathrm{a}$, hal ini menandakan bahwa daun memberikan pigmen yang direfleksikan yaitu berwarna hijau-kekuningan.

\section{UCAPAN TERIMA KASIH}

Penulis mengucapkan terimakasih kepada keluarga dan semua teman yang terlibat dalam penelitian ini. 


\section{DAFTAR PUSTAKA}

Budi Utami, Hasna, P. 2016. Pemanfaatan Zat Warna Hijau Dari Daun Pepaya (Carica papaya L.) Sebagai Pewarna Alami Tekstil. Seminar Nasional Kimia UNY 29 Oktober 2016.

Muniarti, T., Inayati \& Budiastuti, S. (2015). Pengelolaan Limbah Cair Industri Batik dengan Metode Elektrolisis sebagai Upaya Penurunan Tingkat Konsentrasi Logam Berat di Sungai Jenes, Laweyan, Surakarta. Jurnal EKOSAINS, 7 (1), 77- 83.

Neldawati, Ratnawulan \& Gusnedi. 2013. Analisis Nilai Absorbansi dalam Penentuan Kadar Flavonoid untuk Berbagai Jenis Daun Tanaman Obat. Jurusan Fisika. Universitas Negeri Padang. Vol 2 hal : 78.

Rindiy, W., Kusnawati, \& Endang, P. 2010. Ekstraksi Dan Karakteristik Zat Warna Alami Dari Daun Mangga (Mangifera Indica Linn) Serta Uji Potensinya Sebagai Pewarna Tekstil. Universitas Negeri Malang.

Vivin, A., Farida \& Titiek. 24 Juni 2016. Kualitas Pewarna Ekstrak Gambir Pada Batik Sutera. Balai Besar Kerajinan \& Batik. Jurnal Kerajinan Vol. 33, No.1, Juni 2016, Hal 25-26.

Welburn, Harmurt, K., Lichtentaler, Alan, R. 1 oktober 1983. Determinations of total carotenoids and chloropylls $a$ and $b$ of leaf extracts in different solvents. Department of Infection and Immunity. University of Sheffield. Vol 11 hal: 5. Diambil dari : http://www.biochemsoctrans.org/content/11/5/591 